\title{
Editorial
}

\section{Zika, microcefalia, ciência e Saúde Coletiva}

\author{
I Kenneth R. de Camargo Jr. |
}

Este número de Physis traz uma importante contribuição para a discussão sobre uma questão ainda cercada de controvérsias: a possível relação da infecção pelo vírus zika e a ocorrência de microcefalia em crianças filhas de mães infectadas. Ilana Löwy, nome que dispensa apresentaçôes, recupera situações históricas com semelhanças com o presente momento, importante subsídio para a reflexão crítica e - espera-se - a proposição de soluções.

O episódio zika-microcefalia é um caso que merece de fato um exame aprofundado, em que pesem as dificuldades de se fazer uma história do presente, ainda mais no domínio da ciência, com sua fronteira sempre instável.

O que sabemos até o momento é que, em outubro de 2015, uma médica com atuação no Nordeste do Brasil teve sua atenção despertada pelo aumento no número de casos de microcefalia em sua clínica e notificou o Ministério da Saúde. A tempestade resultante, ainda se desdobrando até o presente momento, trouxe repercussões que vão muito além da arena da saúde pública. Uma infecção emergente no Brasil, zika, causada por um flavivírus e propagada por um mosquito já endêmico no país, o A. Aegypti, foi rapidamente apontada como uma possível culpada. Apesar de a grande maioria dos casos identificados ser restrita ao Brasil, a comunidade internacional, incluindo a Organização Mundial da Saúde, rapidamente se inseriu na discussão.

A controvérsia científica se desenrola aos olhos do público, e este está longe de ser um espectador passivo do drama. A internet, em particular as chamadas "redes sociais", tem proporcionado um meio adequado para a proliferação e propagação de discursos concorrentes, não apenas em paralelo, mas estendendo a tradicional troca através de publicações científicas. Muitas revistas científicas tradicionais criaram seçõos de acesso aberto sobre microcefalia e o vírus zika, e adotaram procedimentos acelerados para a aprovação e publicação de artigos sobre o 
assunto, uma oportunidade rapidamente aproveitada por muitos pesquisadores.

Vê-se uma multiplicação de discursos em todos os espaços de circulação de ideias. Diversos atores sociais têm recrutado a controvérsia para promover suas agendas na arena pública, variando de sólidos argumentos científicos a teorias conspiratórias selvagens.

A rigor, estamos longe de poder estabelecer com certeza científica respostas para várias questões pendentes, como qual é a real magnitude do aumento dos casos de microcefalia (supõe-se, com razão, que existiria subnotificação antes de ter sido dado o alarme, e que poderia estar ocorrendo uma supernotificação desde então) e mesmo se de fato a zika seria o agente causal do problema. $\mathrm{O}$ tempo da política pública, entretanto, não é o mesmo da pesquisa científica; os formuladores de política, especialmente de saúde, não podem aguardar uma certeza científica para agir. É certo que temos uma proliferação descontrolada do $A$. aegypti em nosso meio (evidenciada pela persistência da dengue há décadas), que casos de zika estão se multiplicando, possivelmente com outras consequências também graves, como a síndrome de Guillain-Barré, e que há um número importante de casos graves de microcefalia no país. É legítimo, portanto, que se trate esse conjunto de problemas como uma emergência de saúde pública.

Por outro lado, a emergência de novos problemas de saúde pública reitera a conexão entre padrões econômicos, sociais e culturais e o adoecer, mostrando mais uma vez as múltiplas e sinérgicas vulnerabilidades dos mais desfavorecidos.

Esta nova carga se agrega às já existentes sobre um sistema de saúde desde sempre subfinanciado e sem condições de responder plenamente às demandas a que está sujeito; ao mesmo tempo, é este sistema de saúde que conseguiu detectar o novo problema e começa a tentar formular respostas.

Por fim, este novo desafio surge num momento particularmente delicado, de fragilidade política e econômica, que acentua ainda mais as vulnerabilidades sociais, restringe com mais intensidade o aporte de recursos necessários ao SUS e compromete o financiamento da pesquisa, que é certamente um dos componentes essenciais de uma resposta adequada ao surgimento de novos problemas de saúde.

Em suma, mais uma vez queda claro que o adequado enfrentamento de novos e velhos problemas de saúde não se dará sem um redesenho geral de políticas públicas, em especial no que diz respeito à economia. 